\title{
Por la Ruta del Discurso Eurocéntrico en el Cine de Exploradores
}

\section{On the Path of Eurocentric Discourse in the Cinema of Explorers}

\author{
Mónica Villarroel \\ Universidad de Chile \\ monicavillarroelm@gmail.com
}

Resumen - El cine de exploradores en la época silente constituye un discurso sobre Latinoamérica construido desde una lógica eurocéntrica, reproduciendo relaciones de poder donde pueden identificarse rasgos de una colonialidad que, por una parte, enfatiza la modernidad y el progreso y, por otra, resalta las características de exotismo, minusvalía y precariedad de las culturas indígenas locales. Este artículo revisa un conjunto de producciones cinematográficas de exploradores europeos sobre América, a inicios del siglo XX, que evidencian esta perspectiva. Se detiene en un análisis exhaustivo del filme Tierras Magallánicas, del salesiano Alberto de Agostini, dialogando con otras producciones de similar periodo.

Palabras clave: Cine de exploradores, cine silente, estudios sobre cine.

Abstract - The films made by European explorers, in the silent film era, are built on a Eurocentric logic when it comes to Latin America. They reproduce the relationships of power identifying, on the one hand, certain features of colonialism that emphasize modernity and progress, and, on the other hand, highlighting the characteristic exoticism, disability and the precariousness of the local indigenous cultures. The following article will review a number of films by European explorers on America from the early twentieth century, as a support to this perspective. It will conclude with a comprehensive analysis of the film Tierras Magallánicas, from the Salesian Alberto de Agostini, interwoven with other film productions from a similar period of time.

Keywords: Cinema of explorers, silent cinema, film studies. 


\section{INTRODUCCIÓN}

América Latina no sólo fue centro de interés para las exhibiciones de filmes de origen europeo, desde 1896, pocos meses después de que el invento de los Lumière debutara en París, sino que rápidamente se convirtió en un espacio atractivo para las filmaciones de europeos y norteamericanos que registraban, en soportes de nitrato, las «vistas» de un mundo nuevo y exótico. También fue fuente inspiradora para el cine de exploradores, categoría en la que incluimos filmes hoy considerados piezas claves del patrimonio audiovisual del continente, aunque la mayoría fue realizada por extranjeros, y nos permiten un acercamiento al discurso construido desde el otro sobre Latinoamérica o sobre lugares y culturas específicas como la Patagonia en Chile y Argentina y los indígenas fueguinos o la Amazonía en Brasil y Ecuador.

El cine apareció en América Latina como otra importación extranjera, en el marco de la modernidad y del progreso, con una fuerte influencia del positivismo. En su primer momento, se consideraba una diversión y una posibilidad de viajar a tierras lejanas a través de las distintas «vistas» que rápidamente abrieron paso a filmaciones locales realizadas por los camarógrafos Lumière que recorrían el mundo. Esta circulación de técnicos y de imágenes que se producía a fines del siglo XIX y principios del XX, despertó el interés de productoras de Hollywood que filmaron en locaciones latinoamericanas, existiendo unos mil ochocientos títulos entre 1898 y 1935 cuyo tema y/o localización tiene que ver con lo hispano (Stock, 135).

Pero no solo se trataba de la construcción de una imagen del «otro", sino de la construcción del imaginario imperialista, de un discurso sobre el «nuevo mundo» y de una nueva forma de colonialidad. Esta idea nos lleva a poner en vigencia el vínculo entre el cine y las relaciones de poder, el cine y el imperialismo, el cine y la colonialidad, desde las primeras imágenes filmadas en América Latina.

Es crucial, como sustentan Shoat y Stam (142), pensar que el cine surge a fines del siglo XIX, coincidiendo con el apogeo imperialista europeo y norteamericano. Durante el periodo del cine silente, los países líderes imperialistas - Gran Bretaña, Francia, Estados Unidos y Alemania - eran los mayores productores de filmes y tenían un especial interés en difundir y alabar el emprendimiento colonial. El cine se convertía en un «retransmisor» de las narrativas de los imperios y de las naciones, a través de las proyecciones. Agregamos a ello también la idea de «re-transmisor» de los procesos de evangelización y avances de la ciencia, entre otras cosas, potenciadas por eventos como las exposiciones universales o por la necesidad de dar cuenta del «éxito» de misiones evangelizadoras entrado el siglo XX.

Latinoamérica remite a un objeto que ha sido construido desde diferentes lugares: «América» como invención en términos de O'Gorman, objeto que solo se constituyó cuando se pensó desde la diferencia. Nos preguntamos si la identidad latinoamericana es también narrada desde un discurso colonial cuando visionamos películas del periodo silente. Aunque el término colonia refiere a una manera historiográfica y política de clasificar un determinado orden económico, ideológico y cultural, entre fines del siglo XVI y las primeras décadas del s.XIX, esta visión es limitada y no da cuenta de su vigencia. Subrayamos entonces el concepto de colonialidad, en la medida en que éste remite a ca- 
tegorías de pensamiento, a matrices principalmente europeas que siguieron operando a principios del siglo XX y aún son pertinentes.

Una aproximación a este tema es la reflexión sobre la colonización del lenguaje y la memoria planteada desde los estudios poscoloniales. La primera modernidad (s.XVXVII, de acuerdo a Düssel), implicó un proceso de colonización del lenguaje que elaboró no sólo saberes sobre América sino desde América, con una perspectiva colonial y un discurso cristiano teleológico, unitario e inclusivo. Y ello significó un proceso de colonización de la memoria, aunque éste es mucho más complejo, ya que involucra procesos de apropiación, borradura y resemantización. Lo que está en juego aquí es cómo operó también lo que Salomón llama «textualización de la memoria», los relatos que construyeron los españoles sobre los indígenas en una lógica de temporalidad occidental, una narrativa lineal. Podemos hacer extensivo este planteamiento a los discursos cinematográficos realizados por otros europeos (italianos, alemanes, finlandeses) sobre América, ya entrado el siglo XX.

El discurso sobre Latinoamérica considera relaciones de poder a partir del lugar de la enunciación, desde donde se construyó esa idea sobre el "otro». Cuando Said entiende el «Orientalismo» como discurso, como una construcción ideológica y narrativa que implica una superioridad del «otro" europeo, pensamos que América también fue un «Otro» a partir del cual Europa se constituyó como tal, cuando identificó la diferencia y elaboró, ya en la segunda modernidad (s.XVIII y s.XIX), un discurso eurocéntrico sobre América que traslada la ya definida minusvalía y subordinación, a un relato de inmadurez y desde la naturaleza inferior (Buffon cit. en Gerbi), y a un discurso de América como proyecto aún no logrado (Hegel cit. por Gerbi).

A ello agregamos el afán cientificista de la fotografía y el cine en su primer momento, que facilitaba la construcción de un relato sobre tierras no europeas, propiciando contactos visuales con «civilizaciones extrañas»: «La fotografía y el cine representaban topografías extrañas y culturas igualmente extravagantes en relación a Europa. Prolongación de la zoología, la antropología, de la botánica, de la entomología, de la biología y de la medicina, la cámara, a ejemplo de microscopio, disecaba al 〈otro〉 " (Shoat y Stam, 153).

Si bien en una primera época el cine que se exhibió y se filmó en estos confines respondía al «cine de atracciones» o de «curiosidades», muy pronto se vivió un tránsito hacia el documental. Entre ambos, distinguimos el «cine de exploradores» en la época silente (entre 1895 y $1934^{1}$ ), tema que nos ocupa en este trabajo, y que abordaremos a partir de Tierras Magallánicas (1933), del sacerdote salesiano italiano Alberto María de Agostini, filmada entre 1910 y 1930, estrenada en 1933, en contrapunto con filmaciones de Väinö Auer datadas en 1929 y Vuelo de imágenes hacia mundos desconocidos — también traducido como El Cóndor de Plata en Tierra del Fuego (Silberkondor über Feuerland)(1928), realizado por el alemán Gunther Plüschow, que contiene imágenes de distintos puntos de América Latina, incluida la Patagonia argentina y chilena.

El filme de De Agostini fue una de las pocas producciones de la década de 1930 realizadas en Chile que hoy se conservan, existiendo sólo una copia en formato de $35 \mathrm{~mm}$. en el Museo de la Montaña en Turín y otra en 16 mm. en el Museo Salesiano en Punta Are-

\footnotetext{
Si bien el sonido se incorpora al cine en 1927, en América Latina el período silente se extiende hasta 1934 en algunos países como Chile. Escogemos la denominación «silente» y no «mudo", evidenciando que se trata de un periodo en que técnicamente era imposible incorporar sonido, a diferencia del «mudo», que de acuerdo a algunos investigadores, no incorpora sonido o diálogos por opción, siendo técnicamente posible.
} 
nas, y que aborda la temática indígena fueguina. El filme de Plüschow nos permite dialogar con el del salesiano, mientras que un reciente documental Väinö Auer (1895-1981), (2005), del finlandés Mikko Piela, sobre la vida del geólogo también finlandés Dr. Väinö Auer, que contiene imágenes realizadas por el académico en 1929, son complemento para el análisis que aquí realizamos. A modo de apertura, presentamos otras experiencias del cine de exploradores en el continente, en particular, documentos filmados en la Amazonía en la época silente.

En este marco, nos preguntamos cómo se construye el discurso sobre América Latina en los filmes de exploradores a principios del siglo XX y, en específico, en el filme Tierras Magallánicas (1933), de Alberto de Agostini.

Nuestra hipótesis de trabajo es que en el filme del sacerdote italiano el discurso se construye desde el eurocentrismo, con una clara posición de superioridad, y respondería al contexto de producción cinematográfica del cine de exploradores, más que al cine etnográfico propiamente dicho, remitiendo a una dimensión histórica y social del enunciado y de las formas discursivas, idea también presente en los filmes de Plüschow, en los fragmentos de la producción de Auer y en los filmes de Santos, Crespi y Reis, aunque en este último caso, se trate de una producción realizada por un director brasileño formado en Europa.

En algunos casos, no hay duda respecto al carácter latinoamericano de las películas, dado que fueron producidas en este continente con financiamiento local; en otros, no son considerados filmes propiamente latinoamericanos, ya que fueron producciones financiadas y dirigidas por europeos. De todos modos, lo que nos interesa en este trabajo no es el origen del filme, sino su contexto de producción, el lugar donde fue filmado y la mirada sobre Latinoamérica de quien lo realizó.

En un primer momento de análisis, utilizamos como herramienta la de-construcción cinematográfica en el filme de De Agostini, para llegar a la estructura en secuencias y planos, estableciendo su duración y descripción individualizada, identificando motivos que se reiteran en las distintas secuencias, estableciendo su duración y porcentaje de la totalidad de planos, con el fin de obtener una información precisa que nos permitiese analizar la construcción del discurso, aunque nuestro afán aquí no es realizar un análisis estructuralista ni formalista. En un segundo momento, utilizamos el modelo de Mary Louise Pratt en su texto Ojos Imperiales (2002), en una propuesta exploratoria de aplicar la perspectiva usada en la literatura de viajes, a este tipo de cine sobre el que existe escasa investigación. Aunque trabajaremos con un filme de la época silente, indagaremos en el discurso construido a partir de las imágenes y de los enunciados que se explicitan en los intertítulos ${ }^{2} \sin$ entrar en categorías semióticas ni dualismos que restringen el análisis. Nos apoyaremos además, en autores que han abordado el tema del eurocentrismo y la imagen en un contexto socio-histórico. Si bien consideramos que no es pertinente preguntarnos por un único discurso sobre lo latinoamericano, pues es necesario acotarlo a un registro local sin pretender extrapolarlo, sí nos parece oportuno ubicar el filme en su contexto de producción y revisar algunos conceptos y tendencias.

Los intertítulos se usaban en el cine silente para presentar la acción o reproducir diálogos. En este caso, su uso es reiterado (ciento tres cartones) para explicar una acción ya ocurrida o anticipar otra. 


\section{EL PODER DE LAS IMÁGENES}

Gruzinski se refiere a la «guerra de las imágenes» hacia finales del siglo XX, como un acontecimiento que abarca «más allá de las luchas por el poder, temas sociales y culturales cuya amplitud aún somos incapaces de medir». En ese sentido, plantea la paradoja de que hoy estaríamos en un mundo del poder de las imágenes, cuando creemos estar aún bajo el poder del texto. Y se remonta al importante papel que tuvo la imagen en el siglo XVI, en el descubrimiento, conquista y colonización del Nuevo Mundo, indicando cómo ésta fue uno de los principales instrumentos de la cultura europea, un componente de la «gigantesca empresa de occidentalización que se abatió sobre el continente americano», que adoptó la forma de "guerra de imágenes que se perpetuó durante siglos y que hoy no parece de ninguna manera haber concluido» (12).

La cuestión de las imágenes surge desde la época de Colón, cuando los europeos se preguntaron por las imágenes que elaboraban los indígenas y luego la imagen se convirtió en un instrumento de referencia, aculturación y dominio, especialmente vinculado al proceso de evangelización que emprendió la Iglesia Católica, desde la Florida hasta Tierra del Fuego. El autor señala que la América colonial era un crisol de la modernidad porque fue, igualmente, un «fabuloso laboratorio de imágenes» (Gruzinski, 13). Las imágenes o los sistemas de imágenes, lograron que las Indias occidentales entraran en la mira de Occidente, mayoritariamente a través de los imaginarios de los conquistadores, advirtiendo que la imagen, al igual que la palabra y la escritura, puede ser el vehículo de todos los poderes y de todas las vivencias. Esta mirada nos parece relevante para pensar cómo opera la imagen cinematográfica en tanto construcción discursiva. En este sentido, el autor sugiere no realizar un análisis dual (significante/significado, forma/contenido) y compartimentado (lo económico, lo social, lo religioso, lo político, lo estético) para revisar las imágenes, opinión que compartimos al interrogarnos hasta qué punto las categorías y clasificaciones aplicadas a las imágenes son adecuadas.

De acuerdo a Gruzinski (Ibíd), el Occidente cristiano convirtió a los indígenas en objetos de sus debates y los redujo a sus propios esquemas, hasta que se cansó y se volcó hacia otros «exotismos». Esta afirmación es pertinente para pensar cómo un sacerdote salesiano italiano, a comienzos del siglo XX, piensa a los indígenas de la Patagonia en términos cristianos por una parte y, por otra, en términos de «lo exótico», al mismo tiempo que construye su propio imaginario sobre los indígenas fueguinos que luego es difundido y se constituye en un espacio de poder, de quien tiene la cámara en sus manos, entrando en la lógica de la lucha por el control de la memoria, construida desde el otro europeo que no solo controla el lenguaje, en este caso visual, sino también controla el proceso de construcción de la memoria.

Por otra parte, para Emilie de Brigard, el cine etnográfico existe desde el siglo XIX, cuando fue posible el registro visual de los encuentros con otras sociedades, señalando que la definición común se refiere a «aquel que explicita patrones culturales», por lo que todos los filmes podrían considerarse etnográficos, por su contenido, su forma, o por ambos. No obstante, añade que no fue sino hasta los años cincuenta cuando el cine etnográfico se convirtió en una disciplina institucionalizada (18).

Jorge Prelorán en su texto "Conceptos éticos y estéticos en el cine etnográfico», define este registro como «la documentación fílmica sobre los comportamientos humanos, de 
tal manera que las actitudes de la gente, el carácter de sus culturas sean representadas e interpretadas. Este género es una rama del cine naturalista, aunque la nomenclatura indique un énfasis científico, ya que la etnografía es la rama de la antropología que describe las culturas» (124).

En este contexto, De Brigard destaca especialmente al documentalista y geólogo Robert Flaherty con Nanook el Esquimal (1922), calificado como filme de aventuras exóticas, considerada pionero del género documental. Lo que nos interesa aquí es la representación del "otro", la construcción de un discurso sobre los pueblos indígenas a través de la representación cinematográfica, un discurso sobre la alteridad, tomando en cuenta que el género documental se convertía en un híbrido que admitía las puestas en escena, lo que será criticado por Vertov y su ideología del Cine-Ojo, que rechaza todos los elementos del cine de ficción convencional: desde la escritura previa de un guion hasta la utilización de actores profesionales, o puestas en escena oponiéndose a las «representaciones cineteatrales».

El cine etnográfico podría ser un referente para Tierras Magallánicas, en la medida en que registra modos de vida de los fueguinos, aun cuando muchas escenas, al igual que lo que ocurre en el filme de Flaherty sobre los Inuit, son realizadas a partir de puestas en escena o teatralizaciones de costumbres o actividades ya desaparecidas al momento de la filmación.

\section{EXPLORANDO EL CONTINENTE}

Según Ana María López en «Early Cinema and Modernity in Latin America», el período silente en el continente muestra las tempranas formas de modernidad mediatizadas. Se trataba de un «cine de atracciones» o de "curiosidades», diseñado a partir de breves momentos de imágenes en movimiento, un cine de sorpresas, con vistas simuladas, en algunos casos. Aunque ésta puede considerarse la primera etapa en la historia del documental, se trataba de un cine que representaba, entre otras cosas, escenas exóticas, viajes o curiosidades e intereses populares, pero pronto se dio paso a filmes donde estaba presente la mirada de autor e intérprete "que presenta un discurso sobre la realidad representada en la pantalla» (Rolle, 29). El documental propiamente tal, significaba una mirada de autor que se construye a partir de fuentes visuales originadas de la relación entre la cámara y la realidad.

En el mundo destacan algunos documentalistas que transitan entre el cine de curiosidades y el documental de autor. Robert Flaherty, que ya mencionamos, John Grierson, Alberto Cavalcanti y Dziga Vertov, inician una etapa en que se le da contenido a la forma y construyen un discurso de interpretación de la realidad a partir de la evidencia cinematográfica. Representar la vida de pueblos lejanos significaba para el documentalista alcanzar lo que Geertz llamaba «la descripción densa» (cit. en Rolle, 29), es decir, la cultura desde sus lógicas internas, sus expresiones características, y no sólo registrar «curiosidades». Es, no obstante, según Rolle, John Grierson, creador de la Escuela Documental inglesa y canadiense, en los años veinte y treinta del siglo XX, quien utiliza definitivamente el término documental para diferenciarlo de los filmes de las descripciones 
de viajes, las tomas de noticias o las películas de actualidad o variedades, vinculando su actividad cinematográfica a la educación, lo social y la política.

Podríamos sugerir, según estas definiciones, que el cine de exploradores es una categoría distinta, que se sostiene por sí misma. En este sentido, es necesario agregar la clasificación de cine etnográfico que, de alguna manera, aparece también vinculado al cine de exploradores, o cine naturalista, como apunta Prelorán. Nos interesa destacar aquí la contextualización del cine de exploradores que se realizó en América Latina y la forma en que estas producciones, existentes desde los inicios del cinematógrafo en el continente, contribuyeron a la construcción de un discurso y de un imaginario sobre América.

Por otra parte, en América Latina, los antecedentes sobre películas documentales que abordan la temática indígena datan de 1911, con una producción del investigador alemán Theodor Koch-Grümberg, en la frontera de Brasil con Venezuela: Ans Dem Leben Der Taulipang in Guyana (La vida entre los Taulipang de la Guyana). El mexicano Carlos Martínez Arredondo filma en 1912 los documentales Tiempos Mayas y la Voz de la $R a z a$, donde el indígena era representado por costumbres y tradiciones, aunque el tema central eran las luchas por la tierra (Carreño, 47).

\section{SANTOS, REIS Y CRESPI: RELATOS DESDE LA AMAZONÍA}

El cine de exploradores no solo se vinculó a los realizadores extranjeros, aunque hubo otros casos destacables, además de los antes mencionados, como el del portugués Silvino Santos, avecindado en Brasil, que filmó No paiz das amazonas (1922) y No rastro de El Dorado (1925), entre otras producciones que dirigió en esas tierras. Perteneciente a la Cinemateca brasileña, el primero de estos filmes muestra aspectos de la ciudad de Manaos, con pleno funcionamiento de su puerto, los almacenes de la Manaus Harbour, los principales establecimientos comerciales e industriales. Desde allí el espectador se transporta al Amazonas, presencia actividades de pesca y sus habitantes y la preparación del látex. Se exhibe un grupo de indios e indias peruanos, los campos de Río Branco y el Estado de Pará (Belém). La película muestra las riquezas forestales, aves, orquídeas, en fin, la riqueza natural. En la segunda producción documental, Santos presenta aspectos de los ríos Negro y Branco, los servicios de la expedición del estadounidense Dr. Hamilton Rice, los vuelos del avión Eleanor III, tribus de indios que habitan las sierras del Parimã. Hamilton Rice tenía como objetivo la aprobación de un proyecto de construcción de un ferrocarril Manaus-Boa Vista y solicitaba la concesión por treinta años para la explotación de madera y minerales a quinientos metros de cada lado a lo ancho de la línea férrea (Cinemateca brasileña, 35).

En el contexto de la modernidad decimonónica y de principios del siglo XX, la presencia del Estado vinculado al progreso y el desarrollo de nuevas tecnologías se vio representada en el cine silente en países como Brasil o Argentina, donde se registraron experiencias de modernización por una parte $\mathrm{y}$, por otra, se consignaron los modos de vida de comunidades indígenas, en una dicotomía "civilización-barbarie» que debe ser relativizada, dado que en muchos casos, como el de las producciones de Luiz Thomaz Reis en Brasil, la posición respecto al indígena se acercaba más al indigenismo. Reis, un mayor de ejército que estudió cine en Francia y formaba parte de la expedición oficial al 
Amazonas, «la Comisión Rondon», filma entre 1914 y 1938, una serie llamada Ao Redor do Brasil (1932).

Uno de los ejemplos más claros de la influencia del positivismo en el cine de inicios del siglo XX en América Latina es la experiencia conocida como «La Comisión Rondon», que si bien se enmarca dentro del análisis de los pioneros del cine antropológico en Brasil, presenta una asociación directa al registro de la modernización, más allá de la vertiente antropológica. La idea de progreso y civilización-barbarie, aparece como tema de fondo en las imágenes y en los discursos sobre ellas que plasmaron tanto sus defensores como detractores. Otra clave que inspiraba a los integrantes de la expedición y al realizador era la posibilidad de educar al indígena, adscribiendo claramente a tendencias que defendían esta perspectiva. El indigenismo surgía entonces como discurso asociado a estas imágenes de la mano con el concepto de «civilización» basado en la educación y en la capacidad de los pueblos originarios de incorporarse a la modernidad. El propio General Rondon, líder de la expedición, y el realizador Luiz Thomaz Reis encabezaron los discursos en defensa de los indígenas. La Comisión Rondon fue la encargada de implantar las líneas telegráficas en el Mato Grosso y la Amazonía y, entre otras funciones, también debía realizar un levantamiento topográfico y geográfico, de la flora, fauna, mineralogía, etnografía, pacificación de los indios, observación de sus costumbres, lenguas, etc. Como parte del grupo figuraba el mayor de ejército brasileño Luiz Thomaz Reis, encargado del registro cinematográfico y fotográfico, capacitado en la empresa Pathé, en París. La serie Ao redor do Brasil, (1932), de acuerdo a lo que indica el subtítulo, pretendía mostrar «aspectos del interior y de las fronteras brasileñas». En un relato de sus filmaciones, Luiz Thomaz Reis explica que hay escenas «de prácticas inocentes y otras verdaderamente horribles", que justifica por el gusto del público a quien pensaba presentar las filmaciones pues «mientras más bárbara es una escena, tanto mejor para tonificar los nervios gastados de nuestras plateas, ávidas de sensacionalismo» (cit. en De Tacca, 7-8). Fernando de Tacca recoge la polémica civilización-barbarie. A juicio de algunos personajes influyentes, los indios constituían un problema para el progreso y un obstáculo para la colonización del interior del estado de São Paulo, donde los grupos de construcción de las líneas del ferrocarril noroeste de Brasil se veían frecuentemente atacados por ellos. Frente a esta afirmación, el General Rondon respondió airadamente, manifestando que los indígenas tenían capacidad para las artes y la industria y para asimilar las ciencias si es que se les facilitaba una educación esmerada. «[...] no son ellos ni más bárbaros ni más deshumanos de los que, proclamándose civilizados, no trepidan en pregonar el exterminio de una raza entera, bajo el pretexto del progreso y la civilización» (cit. en De Tacca, 7). La Comisión exhibía comercialmente los filmes realizados durante sus trabajos y, en 1918, envió a Reis a Nueva York en una tentativa de lanzar estos filmes en el mercado estadounidense. Rituaes e festas Bororo (1916) fue exhibido junto a un importante número de fotografías y la presentación fue antecedida de una conferencia de Theodore Roosevelt sobre su participación en la expedición Rondon entre 1913 y 1914, relatando su viaje «rumbo a un mundo exótico y desconocido». Esto nos permite proyectar la idea del discurso eurocéntrico hacia Estados Unidos, donde la visión sobre el mundo indígena latinoamericano, particularmente en el caso amazónico, no distaba en muchos aspectos de la perspectiva europea.

La serie Ao redor do Brasil (1932), de Luiz Thomaz Reis recoge la temática del progreso y el interés civilizatorio de los integrantes de la Comisión. Luego de describir la 
vida cotidiana de los indígenas, una escena clave de una de las filmaciones representa el binomio civilización/barbarie, cuando los indígenas son formados, reciben ropas por parte de los «civilizados» y son obligados (hombres y mujeres con el mismo modelo y la misma talla) a vestirse de manera uniformada.

También en la Amazonía, esta vez en Ecuador, el sacerdote salesiano Carlos Crespi filmó Los invencibles shuaras del Alto Amazonas (1927), una película dividida en cuatro partes: la primera en el mar de Génova; la segunda, sobre las costumbres de los Jíbaros y sus formas de caza; la tercera, sobre la fiesta de la Tzanza o cabeza reducida y la cuarta, sobre la obra salesiana en las Misiones del oriente del Ecuador y la del Comité Patriótico orientalista de señoras. El filme se destruyó parcialmente en un incendio, luego fue restaurado y reconstruido por la Cinemateca Nacional del Ecuador en 1995, siguiendo el guión de Carlos Crespi, con siete minutos de la cinta original y fragmentos de archivo que reemplazan el metraje perdido. Un folleto promocional, editado en 1926, indica que el filme narraba el viaje de unos expedicionarios que van en busca de los Shuaras, las tradiciones de estos pueblos y la labor evangelizadora de los Salesianos. Este filme fue realizado estrictamente con fines de difusión y es parte de otras iniciativas de los años 20 en que la sociedad civil y el Estado de Ecuador promovían la colonización del Oriente ecuatoriano y la incorporación de los grupos subalternos: «Una serie de organizaciones conservadoras, en alianza con la Iglesia, proponen acciones tendientes a ampliar la base social del proceso de modernización como forma de contrarrestar los levantamientos indígenas» (León, 5). Al describir el filme, el sacerdote salesiano enfatiza el heroísmo de los misioneros y apela al proceso civilizatorio. «[...] conduce sensiblemente al espectador a amar al Oriente, a apreciar la fuerza prodigiosa de su naturaleza y, sobre todo, a estimar profundamente a la raza jíbara y el heroísmo de los misioneros, que se fatigan a traerla hacia la civilización mundial» (Crespi, cit. en León, 5).

\section{DISCURSOS DE EUROPEOS EN LA PATAGONIA}

Por otra parte, recientemente han surgido dos referencias de producciones cinematográficas que corresponden al cine de exploradores realizado por europeos en la época del cine silente en la Patagonia chilena y argentina, incluyendo un registro de los indígenas fueguinos, aunque no sea éste su tema principal, sino más bien la exaltación de figuras de exploradores o científicos europeos y sus aventuras en el fin del mundo, permitiendo establecer un diálogo con la producción de De Agostini y, al mismo tiempo, poner en discusión la validez de su registro etnográfico, desde el punto de vista de la información que allí se presenta. Si bien no realizaremos un análisis exhaustivo de estos filmes, nos interesa relevar algunos puntos que observamos al visionarlos.

El primero de los filmes, Vuelo de imágenes hacia mundos desconocidos fue realizado por el alemán Gunther Plüschow. Es un relato autobiográfico que narra el viaje de Plüschow, pionero de la aviación, que navegó y sobrevoló cielos patagónicos. Es una descripción de las hazañas del personaje que recorre por mar desde el continente europeo hasta América del Sur con destino final Punta Arenas, donde inició la travesía por aire, en un avión que había sido trasladado por piezas. Si bien en su mayoría se trata de una vasta descripción de paisajes, se construye un discurso que habla del continente ameri- 
cano desde una visión como un mundo de naturaleza exuberante y parajes de majestuosidad, un mundo exótico, pero fundamentalmente, es un relato que además ensalza la colonización alemana en distintos momentos (la alusión más detallada es la referida a la colonia alemana en Brasil), o la superioridad de este país con relación a la minusvalía de los pueblos de Sudamérica en los momentos en que aparece denotativamente esta presencia. Esto se ve reforzado por los intertítulos que, por una parte, destacan la riqueza natural de América, sus cultivos (sobre todo en Brasil, el café, el tabaco, el algodón), su fauna, su geografía, y al mismo tiempo, el foco apunta hacia la inferioridad de la población indígena tanto del interior de Brasil como de la Patagonia (no hay referencia exacta a si es argentina o chilena, pero los indígenas se asocian a una travesía marítima), en relación de oposición a la idea de modernidad, progreso y superioridad de los alemanes, que aparecen asociados a las nuevas tecnologías o a modernos medios de transporte, como aviones y barcos de contrastada presencia escénica con relación a la precariedad de las embarcaciones y la apariencia física de los indígenas.

El filme presenta una descripción exhaustiva de la geografía, incluyendo nombres de ríos, cerros, montes y ventisqueros, pero aludiendo constantemente al «atraso» de este continente, en enunciados como «desaprovechados caen millones de caballos de fuerza» (Pluschöw, El cóndor de plata), como intertítulo que antecede a imágenes de espectaculares cataratas en la región de las Torres del Paine, o al dominio del hombre (europeo) sobre la naturaleza virgen: «el gigante ha sido dominado", "Adiós a la salvaje Patagonia» (Pluschöw, El cóndor de plata), antecediendo a planos generales de guanacos, Torres del Paine y cataratas, conectados mediante fundidos. Especial interés reviste la única escena donde aparecen indígenas de la zona, en una secuencia de planos medios y primeros planos que no alcanza al minuto de duración. Éstos aparecen navegando en una canoa, vestidos a la manera occidental con ropas raídas, al igual que en una de las secuencias del filme de De Agostini. Las imágenes presentan a los indígenas en una situación cotidiana de navegación en su propio medio, aparentemente sin puesta en escena. La secuencia es antecedida por un intertítulo explicativo: «Algunas decenas de indios es el triste remanente de los antiguos aborígenes de Tierra del Fuego» (Pluschöw, El cóndor de plata). La alternancia en el montaje refuerza aún más la idea de minusvalía y salvajismo de los indígenas fueguinos y la superioridad del europeo.

Un segundo filme que mencionamos aquí es Väinö Auer (1895-1981) (2006), del finlandés Mikko Piela, un documental sobre la vida del geólogo también finlandés Dr. Väinö Auer. Académico de gran prestigio en su país natal, Auer realizó varias expediciones a Tierra del Fuego y la Patagonia, registrando imágenes en cine y fotografías que luego publicó en el libro Tulimaata tutkimasssa (Investigación en Tierra del Fuego), ambos documentos datados en 1929. La película de Piela, narrada en primera persona, relata, entre otros acontecimientos de la vida del geólogo, sus estudios y viajes.

Refiriéndose a la importancia de ambos documentos, Martinic señala que el libro contiene fotografías que muestran a tres mujeres sélknam posando junto a uno de los ayudantes de Auer, delante de una de las casas de la estancia «Vicuña», lo que confirma la presencia de estos indígenas en la Tierra del Fuego chilena pasado 1900, por tres o cuatro décadas posteriores a esa fecha, lo que es re-confirmado con la aparición de las imágenes documentales filmadas por el propio Auer en su expedición de 1929 (37-41). Allí se muestra una secuencia de los indígenas en la estancia "Vicuña», el indio Freily, guía de los expedicionarios, un hombre de unos cincuenta años, y su familia, dos muje- 
res jóvenes y una anciana. En el filme de Piela, estas imágenes son acompañadas de una voz en over (aparentemente frases de un diario de Auer) que indica «había usado su arco contra los conquistadores blancos»; "pero abandonadas las hostilidades ahora trabaja en la estancia»; "vio a los blancos disparar contra los indios, eran ingleses dijo [...] les dispararon como si fueran ganado...» (Piela, Väinö Auer).

El documental de Piela compone una producción con un porcentaje importante (alrededor del cuarenta por ciento) de imágenes de archivo, en algunos casos, como las de 1929. Destacan algunas donde Auer es reconocido por su labor como científico y sus investigaciones sobre el cambio climático, acompañadas de un relato donde se pone en relieve su actividad como presidente de sociedades científicas o, las más antiguas, imágenes de la expedición a la Patagonia, donde se muestra a los integrantes del grupo - entre otros, un geólogo, un botánico y un voluntario- en distintos momentos entre 1928 y 1929. Se distingue la incorporación de mapas con una animación que iban dando cuenta del recorrido, lo que también se encuentra en los filmes de Plüschow (1928) y de De Agostini (1933). Por otra parte, hay vistas de la ciudad de Punta Arenas, también registros de la década de los veinte, y registros naturalistas como secuencias de paisajes, loberas, turberas y estancias. Asimismo, aparecen alusiones (en los subtítulos traducidos en castellano de la voz en over) a la modernidad, asociada al desarrollo tecnológico, por ejemplo, con enunciados como «una gran masa de combustible para trenes», para referirse a las colonias de lobos marinos y también a prácticas culturales de los habitantes de la zona que comparten un asado de guanaco al palo con los expedicionarios o bailan cueca entre hombres en una fiesta en la víspera del año nuevo.

Pero sin duda, la secuencia que más llama la atención es un conjunto de planos generales, medios y primeros planos, de quien es descrito como «un viejo cacique indio, vive en las pampas con su esposa...». La imagen presenta una choza, habitada por la mujer indígena vestida con ropas occidentales raídas, y el cacique Pacheko, con atuendos de pieles sobrepuestas sobre pantalones, posando junto a los expedicionarios para la cámara de foto y de cine, en actitud de cacería con arco y flecha, en una imagen idéntica a otra que aparece en el filme de De Agostini. Sólo que en la imagen de Auer, de 1929, la secuencia incluye el primer plano del cacique con su atuendo y luego, un plano general donde se muestra la puesta en escena, es decir, el making off de la filmación, con un texto que acompaña y señala «El cacique Pacheko usó su arco [...] quien en sus tiempos usó su arco contra el hombre blanco trabaja ahora para la compañía Menéndez arreando ganado» (Piela, Väinö Auer). De acuerdo al relato del filme de Piela (2006) Pacheko habitaba en ese tiempo en las cercanías de la estancia «Herminita» (al norte del lago Fagnano), lejos de su tradicional asentamiento en cabo San Pablo al sureste de la isla grande (territorio Haush).

Y agrega que los expedicionarios son presentados al cacique por el estanciero que los recibe como si fueran ingleses, pues los indígenas no podrían imaginar que fueran de Finlandia, lo que refuerza la idea de minusvalía en incapacidad de comprensión de los indígenas, sugerida por el sujeto que enuncia. La voz over es traducida al castellano en subtítulos que componen el resto del enunciado: «el anciano acepta ser fotografiado, pero exige el pago de cinco pesos por adelantado...»; «no es la primera vez en ser fotografiado. Se jactó de haber sido filmado por De Agostini» (Piela, Väinö Auer). Sobre imágenes de los indígenas hay un enunciado concluyente: «Las hermosas series de imágenes de indígenas salvajes que habíamos visto en Punta Arenas eran representaciones armadas» (Piela, 
Väinö Auer). En este caso, en oposición al enunciado anterior, se sugiere la astucia del indígena.

Otros enunciados se refieren a «indefensas poblaciones indígenas»; «la crueldad de los blancos contra los indios»; «los sobrevivientes de un pueblo en extinción» (Piela, Väinö Auer). Las imágenes de archivo incluyen a los expedicionarios y sus travesías por agua y tierra, a caballo, por el interior, dando cuenta siempre del hermoso paisaje, con glaciares, ríos y montañas, pero aludiendo al mismo tiempo a la rigurosidad de esta tierra «salvaje», y al retorno hacia la "civilización», en el camino de regreso hacia Buenos Aires recorriendo laderas de montaña.

Tanto la descripción exhaustiva de la geografía, el recorrido de tierras interiores y la alusión a la modernidad y al atraso, con algunas variaciones, son reiterados en Plüschow, Auer y De Agostini. La visión del indígena también sugiere una mirada desde el europeo, abordando desde la inferioridad hasta el salvajismo y la indefensión, hasta la astucia.

\section{DE AGOSTINI Y SUS TIERRAS MAGALLÁNICAS}

Siguiendo la propuesta de Pratt respecto a la literatura de viajes y exploraciones, aplicamos su análisis al cine de exploradores, específicamente en la obra Tierras Magallánicas (1933), de Alberto de Agostini. La autora asocia el expansionismo imperial a la literatura de viajes y encuentra dinámicas afines de poder y apropiación, expresando que la elaboración de discursos que legitiman la autoridad burguesa y descalifican modos de vida campesinos y de subsistencia, tendría un trasfondo ideológico que se instaló en lugares diversos desde África del Sur o Argentina hasta la misma Europa. Se refiere a que con frecuencia los textos son «trabajos celebratorios y recapitulan las hazañas de excéntricos intrépidos o científicos esforzados» (32). Estos trabajos son documentales, se apoyan en los relatos de viajes como fuentes de información sobre los lugares, pueblos y épocas que estudian.

Una primera observación es que la película formaría parte de lo que la autora identifica como producción de la idea de «el resto del mundo" para los lectores europeos en determinados puntos de la trayectoria expansionista de Europa, en este caso, predominantemente en lo referido a la expansión del catolicismo (la congregación salesiana particularmente) y de lo que De Agostini atribuye a un proceso de colonización (no identificada específicamente en el filme) en la zona de Magallanes. Ya desde el siglo XVI, la historiografía relata la explícita presencia de la Iglesia Católica, incluyendo no solo las instituciones, prácticas, sino el traslado de misioneros que instalaron parroquias y diócesis, difundiendo el cristianismo, además de la imposición de la lengua, la legislación, la arquitectura y la construcción de las ciudades. Si bien no ahondaremos aquí sobre el proceso de evangelización, nos parece importante señalar que éste continuó desarrollándose en el contexto del siglo XX, en la zona Patagónica. El imaginario imperial que Pratt identifica en la literatura de viajes, en el filme no solo se referiría a la expansión del catolicismo, sino a la idea de modernidad de fines del siglo XIX y primeras décadas del $\mathrm{XX}$, asociada a la incorporación de nuevas tecnologías (incluido el cine), al desarrollo industrial y a la idea de progreso vinculada a la importación en América de tecnologías venidas principalmente de Europa (Inglaterra o Francia en el caso del cine). 
Tierras Magallánicas fue concebido para su exhibición en Europa, hecho que se confirma con su estreno el 26 de mayo de 1933, en el cine teatro Politeama Chiarella de Turín. La película construye un discurso sobre «el otro» no europeo, desde el europeo, considerando aquí un discurso sobre los indígenas de la zona de Tierras Magallánicas y de los habitantes de zonas urbanas, un discurso sobre la geografía, el paisaje, la flora y fauna; un discurso sobre la Patagonia argentina y chilena, que en la mayoría del filme aparece como un único espacio solo diferenciado por la aparición de mapas que apuntan el recorrido de la expedición y la referencia a los centros urbanos o, al final, una bandera chilena.

Un 22,6\% del total de planos, agrupados en cinco secuencias (de un total de veinte), es decir, ochenta y nueve planos (de un total de trescientos noventa y dos), aluden a los indígenas, mostrándolos en distintas facetas, tanto en su hábitat natural como en espacios como misiones o ya occidentalizados. Pero esta construcción del otro no europeo en la película de De Agostini, también considera una visión del «otro» moderno, con ocho secuencias que se refieren a puertos, ciudades y desarrollo de actividades productivas industriales (vistas del Puerto y la ciudad en Punta Arenas, Ushuaia, Puerto Natales, frigoríficos, procesamiento industrial de la madera, la centolla y de la lana, automóviles, entre otros), con ciento veinticuatro planos, un $31,6 \%$ del total.

Pratt alude a que esta construcción del «resto del mundo» refiere a cómo tales prácticas significadoras codifican y legitiman las aspiraciones de expansión económica y construcción de un imperio, entre otras cosas. Otro de los temas que aborda es la relación entre la literatura de viajes y la historia natural de la ilustración y cómo ambas se potenciaron para producir una "conciencia eurocentrada global o planetaria», caracterizada por «una orientación hacia la exploración interior y la construcción de significado en escala global, a través de los aparatos descriptivos de la historia natural» (38). Entre otras expediciones, la autora destaca la de Le Condamine (1735) como un triunfo para la comunidad científica europea, al mismo tiempo que el relato de este viaje también fue un referente para la «literatura de supervivencia», consignando la narración de peligros y dificultades atravesadas y las maravillas y curiosidades vistas. Esta experiencia marca el inicio de una era de viajes científicos y de exploración interior, lo que indica un cambio en la concepción de Europa de sí misma y de sus relaciones globales.

Los tres filmes referidos a la Patagonia muestran esta tendencia de recorrer tierras interiores, con los protagonistas y otros miembros de las expediciones adentrándose en la cordillera magallánica con la cámara y a caballo. La película de De Agostini, al igual que la de Plüschow y las imágenes de Auer, narraban también las dificultades atravesadas y las curiosidades vistas en un territorio descrito al mismo tiempo hostil y maravilloso. De Brigard destaca la dificultad que significaba filmar en terreno en los primeros años del cine, a fines del siglo XIX: pesadas cámaras, película de baja exposición que exigía filmar de día, considerando además la gran inflamabilidad del material nitrato y el peligro que conllevaba su transporte (20). Podemos extrapolar esta dificultad a las producciones documentales realizadas por los exploradores que recorrieron distintos puntos de América Latina, a principios del siglo XX, lo que convertía a estas primeras filmaciones en verdaderas hazañas.

A partir de 1735, la construcción de un conocimiento a partir de clasificaciones botánicas, una taxonomía con parámetros visuales instalados por Linneo también es un referente para la literatura de viajes. Lo que nos interesa aquí es que en la segunda mitad del 
siglo XVIII, todas las expediciones, científicas o no, y todos los viajeros, científicos o no, tuvieron algo que ver con la historia natural y que la naturaleza se tornó narrable. Surge una narrativa «anticonquista», que tuvo una gran fuerza ideológica durante el siglo XIX y sigue vigente hasta hoy, consistente en que el naturalista naturaliza la presencia y la autoridad de la Europa burguesa. Aparece en Europa entonces el interés por preservar, transportar, exhibir y documentar los especímenes, desarrollándose especializaciones del dibujo artístico, botánico y zoológico. El naturalista puede ser definido como un tipo social, con una imagen utópica de un sujeto burgués europeo «simultáneamente inocente e imperial, imponiendo una visión hegemónica inofensiva, que no instala aparato alguno de dominación» (Pratt 68).

Alberto María De Agostini coincide con esta definición, aunque su pertenencia a una orden religiosa agrega otros elementos. Nacido en Pollote, Italia, en 1883 (falleció en Turín 1960), pertenece a una familia de cartógrafos. En 1909 se ordena sacerdote de la Congregación Salesiana y elige viajar a la Patagonia, donde viven, desde 1878, los misioneros de don Bosco. Se incorpora a trabajar en las misiones itinerantes, práctica que los salesianos desarrollaron luego del incendio de su principal misión. El padre De Agostini, escalador de montaña, científico, fotógrafo y cineasta, tiene así la oportunidad de viajar por todo el territorio patagónico. Ya en 1910 inicia sus investigaciones con registros fotográficos del río grande y la isla Dawson, que luego publica en 1924 en Turín, bajo el título Mis viajes a Tierra del Fuego, incluyendo 340 fotografías. Publicó alrededor de veinte obras y realizó dos documentales, filmados en distintas etapas, a partir de 1918. Fue miembro de varias sociedades científicas internacionales y, como tal, integra una expedición a los setenta y tres años, para escalar el monte Sarmiento en Tierra del Fuego.

La ciencia creó imaginarios globales más allá y por encima del comercio, a nivel de ideología, y De Agostini no estuvo ajeno a ese interés científico, al igual que el geólogo finlandés Väinö Auer. Pero la sistematización de la naturaleza, más allá de un discurso europeo sobre mundos no europeos, implicaba un discurso urbano sobre mundos no urbanos, un discurso burgués y culto acerca de mundos campesinos e incultos y las sociedades de subsistencia empezaron a aparecer atrasadas respecto a modelos orientados hacia el excedente y se pensó que era necesario mejorarlas.

En Tierras Magallánicas, pueden contabilizarse cinco secuencias y ciento setenta y dos planos correspondientes a paisajes, geografía, flora y fauna, siendo un $43,9 \%$ del total de los planos de la película. Muchas de estas imágenes responden a la idea de exploración del interior, incluyendo la secuencia de «ovejeros en la montaña» (siete planos), imágenes de estancias y de indígenas filmados en territorios interiores.

El discurso del filme se construye a partir del sujeto expedicionario, naturalista y sacerdote, concordante con el tipo social de naturalista definido por Pratt, es decir, es simultáneamente inocente e imperial, pero sí nos parece que construye un discurso hegemónico desde la religión, proponiendo que la «salvación» de los indígenas estaba en las misiones. El perfil del sacerdote coincide en varios aspectos con el de Auer, es decir el científico (uno geólogo, el otro cartógrafo), naturalista y explorador, que se ajusta a la narrativa de anticonquista.

Lo que se observa en los tres materiales cinematográficos es la construcción de un discurso de la alteridad, lo que juega un rol fundamental en su construcción identitaria de Europa, como sostiene Pratt, al igual que Said. La metrópoli imperial tiende a comprenderse a sí misma como determinadora de la periferia, en relación a su «misión 
civilizadora», manifestando también una especie de necesidad obsesiva de representar continuamente sus periferias, sus otros, ante sí misma, sin prestar atención a los modos en que éstos la representan.

El discurso sobre Latinoamérica que plantea la idea de minusvalía, subordinación e inferioridad citada al comienzo, puede proyectarse a algunos ejemplos del cine de la época silente realizado por europeos y, específicamente, al cine de exploradores y a Tierras Magallánicas. En la época en que se instala la producción cinematográfica que analizamos, es decir, la década de 1930, está operando el concepto de colonialidad, observada no solo en una mirada desde las estructuras socio-económicas, sino desde la geopolítica del conocimiento. El discurso de la modernidad es el que justifica el discurso de la colonialidad, que puede pensarse desde los ejes claves para la dominación: el control de los imaginarios y la imposición de categorías epistémicas (Walter Mignolo, "Colonialidad global, capitalismo y hegemonía epistémica», 55-88). Pensamos que filmes como Tierras Magallánicas constituye también un control de los imaginarios y de la memoria, siguiendo la idea de Mignolo, al mismo tiempo que impone categorías epistémicas.

Por otra parte, Pratt utiliza la expresión «zona de contacto» refiriéndose a la «presencia conjunta, espacial y temporal, de sujetos — anteriormente separados por divisiones geográficas e históricas- cuyas trayectorias se intersectan» (26). Al usar el término "contacto", enfatiza las dimensiones interactivas y de improvisación de los encuentros coloniales, poniendo de relieve que los sujetos se constituyen en y por sus relaciones mutuas. En ese sentido, aborda las relaciones entre viajeros y visitados o colonizadores y colonizados enfatizando la co-presencia y la interacción, pero también en el marco de la dificultad de comprensión y prácticas, muchas veces enmarcadas en relaciones de poder asimétricas. Propone hablar de la "anticonquista», como ya mencionamos, para referirse a las estrategias de representación por medio de las cuales «los sujetos burgueses europeos trataban de declarar su inocencia en el mismo momento en que afirman la hegemonía europea». El protagonista de la anticonquista es el «veedor», sujeto europeo del discurso del paisaje europeo "aquel cuyos ojos imperiales pasivamente observan y poseen» (27).

El filme de De Agostini, construye un discurso que enfatiza la idea de «misión civilizadora» y podríamos incluir aquí la idea de «misión evangelizadora». En ese marco, identificamos dos secuencias y veintiún planos que aluden explícitamente a la evangelización y a la misión salesiana en la Patagonia, alcanzando un 5,3\% del total de planos. A ello sumamos una secuencia de «indígenas civilizados», que funciona utilizando la alegoría como recurso en un montaje alternado con una domadura de caballos.

Varias secuencias remiten a la idea de «zona de contacto». Entre ellas, la de los tehuelches, donde aparece el propio protagonista evangelizando a los indígenas, en un espacio de encuentro entre visitante y visitados. No obstante, podemos pensar que espacios como las fábricas (de centolla o de procesamiento de lanas) también podrían constituir zonas de contacto donde los indígenas llegaron a desarrollar trabajos como operarios. No obstante, donde hay referencia concreta es a la actividad ovejera, es decir, la estancia sería una zona de contacto, dado que ése sería el espacio donde «los pocos indios onas se han transformado en hábiles ovejeros y valientes jinetes» (De Agostini, Tierras Magallánicas).

Otro término que propone Pratt es el de «autoetnografía» o «expresión autoetnográfica", refiriéndose a los casos en que «los sujetos colonizados se proponen representarse a sí mismos de maneras que se «comprometen con〉 los términos propios del colonizador» 
(27). Este concepto de "autoetnografía» nos parece aplicable en la cinta de De Agostini en la medida en que identificamos a lo menos seis secuencias donde los indígenas se representan a sí mismos del modo en que es solicitado por el director del filme. La primera identificación de este trazo, es la mirada directa a la cámara, luego la idea de «posar» para la cámara de cine en varios momentos, y, finalmente, la más evidente, es cuando el sujeto colonizado construye una dramatización de sí mismo y de sus prácticas culturales.

La que más llama la atención es la hoy cuestionada secuencia del cacique ona Pacheko y su familia. La secuencia incluye escenas de caza dramatizadas, una escena de curación con ritual con dos protagonistas, el médico y el enfermo, con la acción de pintarse el rostro como parte del rito; elaboración de flechas con madera de haya y tripas de guanaco; mujeres cosiendo pieles de guanaco y alusión a la curtiembre de las mismas; mujer elaborando cestas, niño jugando con guanaco, pintura de rostros de mujeres con barro. Todos los indígenas aparecen vestidos solo con pieles, en algunos casos con el torso semi desnudo.

«Pa-chek- anca ancha, el último gigantesco representante de los fuertes onas nos trae un cordial saludo con su habitual jovialidad» (De Agostini, Tierras Magallánicas). Este enunciado del intertítulo refuerza la imagen a la que alude, constituyendo un relato visual y al mismo tiempo escrito de la idea de autoetnografía, ya que el cacique se representa a sí mismo para la cámara. Lo mismo ocurre con la imagen de la sanación, que es reforzada con el siguiente texto: «La buena reputación de que goza este médico (Kon) lo ha colocado en un alto grado de superioridad entre los escasos sobrevivientes de la tribu» (De Agostini, Tierras Magallánicas).

Una imagen de esta secuencia donde claramente el indígena obedece a las órdenes del director-viajero-evangelizador, es un plano medio donde el sujeto colonizado muestra sus dientes a la cámara, con el siguiente enunciado «los dientes son sanos y de sorprendente blancura por el continuo uso que ellos hacen en la masticación de tendones y en la elaboración de las flechas, van perdiendo su agudeza hasta quedar completamente chatos» (De Agostini, Tierras Magallánicas).

Basándonos en la comprobación de las imágenes de Auer (1929) incluidas en el documental de Piela (2006), confirmamos que esta secuencia constituye una representación, un relato sobre sí mismos, construido por indígenas ya colonizados que incluso habrían cobrado a De Agostini por la actuación en la película. Podríamos sugerir que las secuencias de yaganes, tehuelches y alacalufes, también obedecen a esta lógica de representación, en que el indígena realiza una autoetnografía y el visitante, en este caso el director de la película, elabora un discurso con la imagen donde se muestra a un indígena en situación de inferioridad y minusvalía (especialmente en el caso de los alacalufes), hambrientos, andrajosos y en situación de precariedad, en una secuencia de casi dos minutos. Nuevamente por contraste a través del montaje, aparece la salvación de estos sujetos inferiores por la presencia de la Congregación Salesiana. Las imágenes que siguen a la secuencia de indígenas hambrientos en una canoa, muestran a tres sacerdotes salesianos y luego a la casa de la misión con monjas enseñando a mujeres y niñas ya vestidas a la manera occidental, tejiendo, cosiendo y con apariencia de bienestar. Los textos que acompañan la secuencia son parte de los enunciados que sugieren la idea de «salvación» y «civilización»: «Para proteger y confortar estas míseras poblaciones surgieron las misiones salesianas de Don Bosco fundadas por el intrépido misionero Mons. Fagnano»; «Las 
mujeres bajo paciente guía de las hermanas de María Auxiliadora aprendían a hilar y a tejer lana» (De Agostini, Tierras Magallánicas).

\section{EPÍLOGO}

Al comienzo de este trabajo nos preguntamos cómo se construye el discurso sobre la Patagonia y sobre los indígenas de la región en el cine de exploradores de principios del siglo XX y en específico en el filme Tierras Magallánicas (1933), de Alberto de Agostini.

Para realizar el análisis usamos la técnica de la de-construcción cinematográfica, distinguiendo un total de veinte secuencias y trescientos noventa y cinco planos (tres de los cuales no consideramos por corresponder a una presentación incluida en forma posterior, en la edición en DVD), describiendo cada uno de ellos en una planilla que sintetizamos en las tablas anexas. Es importante señalar que si bien se observó un manejo del montaje cinematográfico para establecer relaciones de oposición, asociación o contraste en algunas oportunidades, la película es, en su mayoría, filmada en planos generales que buscan resaltar el tema del paisaje. Podríamos pensar que se trataría, de algún modo, de la reiteración del motivo edénico, presente en el imaginario de los naturalistas.

El plano americano, el plano medio y el primer plano, son usados escasamente, fundamentalmente en algunos momentos donde se presenta a los indígenas. Si bien hay recursos de la época como el iris (en dos oportunidades), no hay un uso de la técnica cinematográfica más allá de los elementos básicos. La película de De Agostini se enmarcaría en la tendencia de "transparencia del discurso fílmico», en la clasificación de Aumont, es decir, la desvalorización del montaje como tal y la sumisión estricta a su instancia narrativa o a la representación realista del mundo, consideradas como el objetivo esencial del cine para algunos realizadores. Esto nos abre una nueva pregunta, al cuestionar si esa transparencia es tal, desde el momento en que el realizador-montajista es un sujeto que construye un discurso desde un lugar determinado, aunque tenga un manejo incipiente de la función semántica del montaje. Nos preguntamos si el eurocentrismo del sujeto que enuncia constituiría también un juicio ideológico, al naturalizar la figura del explorador y evangelizador, componiendo a través de la imagen, una figura mísera y minusválida del indígena. Esta visión y construcción de la alteridad contribuiría también a que Europa se pensase a sí misma, como lo plantea Said, a partir de la diferencia.

Comprobamos nuestra hipótesis de trabajo al constatar que el discurso en Tierras Magallánicas se construye desde el eurocentrismo, con una clara posición de superioridad, desde el sujeto que enuncia, remitiendo a una dimensión histórica y social del enunciado y de las formas discursivas.

Pudimos identificar los elementos que propone Pratt para analizar la literatura de viajes, reconociendo tendencias como la exploración de tierras interiores, la construcción de una narrativa fuertemente arraigada en la historia natural, la geografía y el paisaje; la tipificación del sujeto que enuncia como «el naturalista», protagonista de la «anticonquista», que es al mismo tiempo un evangelizador que sugiere la expansión del cristianismo.

La «misión civilizatoria» del cura cineasta europeo, se completa con la «misión evangelizadora", construyendo con la cámara un discurso sobre los indígenas fueguinos y sobre la identidad patagónica en general. Podemos identificar aquí un eurocen- 
trismo epistemológico y un discurso que contiene las categorías de subalternidad, inferioridad, o las dicotomías centro/periferia; dominador/dominado; civilización/barbarie; civilización/progreso. No obstante, esta categorización resulta insuficiente para abordar la perspectiva de un cine de exploradores que sugiere también un discurso científico, naturalista, misionero, en este caso específico, que utiliza estrategias que al mismo tiempo exaltan la belleza del paisaje o las hazañas de los exploradores.

Tanto en las imágenes de Auer como en los filmes de Plüschow y de De Agostini puede vislumbrarse la idea de Pratt en relación a que se trata de trabajos celebratorios, que recapitulan las hazañas de excéntricos intrépidos, como el caso del piloto alemán, o científicos esforzados, como el caso de Auer y De Agostini, quien además aparece como un evangelizador, al igual que Crespi.

Podemos concluir, retomando a Gruzinski, que en el caso de Tierras Magallánicas y de los otros dos filmes que referimos, se configura un sistema de imágenes desde el imaginario de los realizadores-exploradores, permitiendo que la Patagonia entre en la mira de Europa a fines de los años veinte y en la década de los treinta del siglo XX, siendo el cine un vehículo de poder y una nueva forma de dominación. Interesante nos parece la reiteración de imágenes que resaltan la cartografía, no solo en el caso de De Agostini, denotando el territorio que se recorre durante el viaje y connotando la conquista. La idea de modernidad y progreso, la producción industrial, los modernos medios de transporte, también indican la presencia de un discurso sobre la modernidad y el progreso que elude las tensiones, idealizando el concepto de «civilización» y reforzando la idea de la representación de la «barbarie» como alteridad.

Lo anterior nos lleva a concluir que el discurso eurocéntrico que construye Tierras Magallánicas desde un sujeto europeo que enuncia, mantiene vigente la idea de colonialidad en las primeras décadas del siglo XX. Los «ojos imperiales», elaboran el discurso de lo «exótico» por una parte, y por otra, lo inferior, lo susceptible de ser educado en la fe y en el conocimiento, desde la perspectiva «iluminada» de la modernidad.

Finalmente, nos parece posible considerar que el trabajo de De Agostini responde a algunas características del cine documental que lo distinguen del cine de atracciones que registraba hechos sorprendentes. Hay aquí un punto de vista autoral incipiente desde la óptica cinematográfica, y una construcción de discurso que, si bien, no reuniría todas las exigencias de un cine realizado con parámetros científicos, incorpora elementos del cine etnográfico. La película transita entre un cine de atracciones y el documental, siendo plenamente identificado con lo que denominamos el «cine de exploradores», en un contexto donde el cine realizado por europeos sobre América tendía a presentar una construcción de la alteridad donde predominaba aún la idea de «lo exótico", no obstante, se identificaba ya una mirada de autor que exploraba otros recovecos, construyendo un imaginario y una memoria sobre la Patagonia en particular. Este imaginario, no sólo incluía una visión sobre el indígena, sino sobre la modernidad y el progreso, motivo dominante en los documentos cinematográficos de fines del siglo XIX e inicios del XX.

Proponemos, finalmente, que es posible trazar una categoría de cine de exploradores, que puede considerarse parte de los inicios del cine documental, que no es un cine de atracciones, ni tampoco un cine etnográfico a cabalidad. Este cine de exploradores encuentra un referente en la literatura de viajes. Su definición teórica y su caracterización precisa es un territorio aún por explorar. 


\section{ANEXO 1}

Tabla 1: Tierras Magallánicas (1933): Motivos

\begin{tabular}{|l|r|r|r|r|}
\hline Motivos & $\begin{array}{r}\mathbf{N}^{\mathbf{0}} \text { de } \\
\text { secuencias }\end{array}$ & $\begin{array}{r}\mathbf{N}^{\mathbf{o}} \text { de } \\
\text { planos }\end{array}$ & $\begin{array}{r}\text { Duración } \\
\text { en min. }\end{array}$ & $\begin{array}{r}\text { Porcentaje } \\
\text { de planos }\end{array}$ \\
\hline Vistas de puertos y ciudades y modernidad & 4 & 38 & 6.0 & $9.7 \%$ \\
\hline Paisajes, geografía, flora y fauna & 5 & 172 & 23.2 & $43.9 \%$ \\
\hline Ovejeros en la montaña & 1 & 7 & 1.19 & $1.8 \%$ \\
\hline Evangelización & 2 & 21 & 3.27 & $5.3 \%$ \\
\hline $\begin{array}{l}\text { Actividades productivas industrializadas } \\
\text { (maderera, lanar, centollas) }\end{array}$ & 3 & 86 & 13.82 & $21.9 \%$ \\
\hline $\begin{array}{l}\text { Indígenas en estado ‘natural〉 (tehuelches, onas, } \\
\text { yagananes, alacalufes) }\end{array}$ & 3 & 55 & 12.56 & $14.0 \%$ \\
\hline Indígenas «civilizados〉 & 2 & 13 & 1.37 & $3.3 \%$ \\
\hline Total & 20 & 392 & 61.41 & \\
\hline $\begin{array}{l}\text { Nota: no se incluye presentación y se reitera } \\
\text { tehuelches en evangelización }\end{array}$ & & & & $99,9 \%$ \\
\hline Total planos sobre indígenas & 5 & 89 & 17.2 & $22 \%$ \\
\hline
\end{tabular}

Tabla 2. Tierras Magallánicas (1933): descomposición en secuencias y planos

\begin{tabular}{|l|l|r|r|}
\hline $\begin{array}{l}\mathbf{N}^{\circ} \text { de } \\
\text { secuencia }\end{array}$ & Descripción de secuencia & $\begin{array}{r}\mathbf{N}^{\mathbf{o}} \text { de } \\
\text { planos }\end{array}$ & $\begin{array}{r}\text { Duración } \\
\text { en min. }\end{array}$ \\
\hline 1 & Presentación & 3 & 1.08 \\
\hline 2 & Vistas del puerto en Magallanes & 11 & 1.48 \\
\hline 3 & Vistas de la ciudad & 9 & 1.18 \\
\hline 4 & Vistas Puerto Natales y Puerto Bories & 7 & 2.17 \\
\hline 5 & Paisaje montaña y río turbulento & 63 & 7.58 \\
\hline 6 & Ovejeros en la montaña & 7 & 1.19 \\
\hline 7 & Paisaje con hielos, glaciares y ventisqueros & 23 & 3.10 \\
\hline 8 & Fauna salvaje (puma y zorro) & 6 & 0.22 \\
\hline 9 & Misionero e indígenas tehuelches, evangelización & 8 & 0.51 \\
\hline 10 & Paisaje montañas y canales & 15 & 4.05 \\
\hline 11 & Ushuaia, iglesia & 1 & 0.10 \\
\hline 12 & Tala de árboles & 5 & 1.27 \\
\hline 13 & Pesca y procesamiento industrial de centolla & 34 & 4.25 \\
\hline 14 & Paisaje navegación y pingüinos, albatros, gaviotines y focas & 65 & 8.25 \\
\hline 15 & Indígenas onas, Pachek, y familia, caza, medicina indígena, & 31 & 8.02 \\
& pintura del cuerpo, cestería & & \\
\hline 16 & Indígenas yaganes y alacalufes & 24 & 4.03 \\
\hline 17 & Misión salesiana con indígenas evangelizados & 13 & 2.36 \\
\hline 18 & Indígenas civilizados y caballos domados & 13 & 1.37 \\
\hline 19 & Colonización actividad ovejera industrial & 47 & 8.30 \\
\hline 20 & Paisaje con automóvil y estancia & 10 & 1.07 \\
\hline & Total & 395 & 61.58 \\
\hline
\end{tabular}




\section{ANEXO 2}

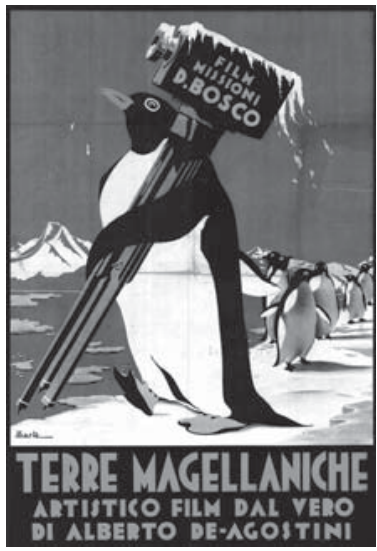

Ficha ${ }^{3}$ Tierras Magallánicas (Estreno 1933, Mediometraje silente $35 \mathrm{~mm} \mathrm{~b} / \mathrm{n}, 62 \mathrm{~min}$.)

Director, fotografía y cámara: Alberto María de Agostini

Productor: Congregación Salesiana

Sinopsis: «En el extremo sur de Chile y Argentina se encuentran las tierras magallánicas formadas por Tierra del Fuego y Patagonia. En su parte occidental, de múltiples canales y bosques, viven nómadas onas (Selk`nam) y yámanes (yaganes). En la región oriental de estepas, habitan tehuelches (patagones). Los tres grupos en extinción, por epidemias mundiales de gripe que derivan en tuberculosis, son asistidos por misioneros de la Congregación Salesiana. Descritos los lugares geográficos y presentados algunos aborígenes (un chamán ona fabrica su arco de haya y realiza una curación, mujeres onas cosen pieles, un grupo de yámanes construye una canoa de corteza de haya), la cámara da cuenta de la próspera ciudad de Punta Arenas y de algunas bien equipadas estancias ovejeras. La información se entrega a través de escuetos títulos escritos en letras blancas sobre fondo negro» (Vega, 90).

\section{REFERENCIAS}

Andermann, Jens. The optic of the State. Visuality and power in Argentina and Brazil. Pittsburgh: University of Pittsburgh Press, 2007. Medio impreso.

Ao redor do Brasil. Reis, Luiz Thomas, dir. b/n. 1932, Medio fílmico.

Aumont, Jacques. Estética del cine. Barcelona: Paidós, 1995. Medio impreso.

Carreño, Gastón. «Miradas y alteridad. La imagen del indígena latinoamericano en la producción audiovisual». Tesis para optar al grado de Magíster en Estudios Latinoamericanos. Universidad de Chile, 2007. Medio impreso.

Escogemos la ficha de Alicia Vega (2006) y la sinopsis de la autora. Modificamos la duración, dado que la copia en dvd que utilizamos para este trabajo dura $62 \mathrm{~min}$. La copia en dvd tiene por título Patagonia. 
Cinemateca Brasileira. Catálogo III Jornada de cinema silencioso. Sao Paulo, Brasil. Medio impreso.

De Brigard, Emilie. «Historia del Cine etnográfico». Imagen y Cultura. Perspectivas del cine etnográfico. Ardévol, Elisenda Piera y Luís Pérez-Tolón (coord.). Granada: Diputación provincial de Granada, 1995. Medio impreso.

Düssel, Enrique. «El eurocentrismo». 1492. El encubrimiento del otro: hacia el origen del «mito de la Modernidad». La Paz: Plural Editores, 1994. Medio impreso.

El Cóndor de Plata en Tierra del Fuego (Silberkondor über Feuerland). Plüshow, Gunther, dir. b/n. DVD, 2006. 1928. Medio fílmico.

Foucault, Michel. La Arqueología del Saber. México: Siglo XXI, 2001. Medio impreso.

Gerbi, Antonello. «Prólogo», «I. Buffon: la inferioridad de las especies animales en América». La disputa del Nuevo Mundo. Historia de una polémica 1750-1900. México: FCE, 1993. 3-31. Medio impreso.

Grunzinski, Serge. La guerra de las imágenes. De Cristóbal Colón a Blade Runner (1492-2019). México D.F.: Fondo de Cultura Económica, 2006. Medio impreso.

Gunning, Tom. «Now you see it, now you don't): The temporality of the cinema of attractions». The Silent Cinema Reader. Eds. Grieveson, Lee, y Peter Kramer. London and New York: Routledge, 2004. Medio impreso.

León, Christian. «Racismo, políticas de la identidad y construcción de ‘otredades〉 en el cine ecuatoriano». Revista Chilena de Antropología Visual 5 (2005). 91-100. Medio impreso.

López, Ana María. «Early Cinema and Modernity in Latin America». Cinema Journal 40/1. Texas: University of Texas Press, 2000. Medio impreso.

Los invencibles Shuaras del Alto Amazonas. Crespi, Carlos (dir.). b/n. 1926. Medio fílmico.

Martinic, Mateo. «Nueva Evidencia sobre la presencia Selknam tardía en la Tierra del Fuego Chilena». Revista Magallania 36/1 (2008). 37-41. Medio impreso.

Mignolo, Walter. «La colonización del lenguaje y de la memoria: complicidades de la letra, el libro y la historia». Discursos sobre la «Invención» de América. Zavala, Iris (coord.). Amsterdam: Rodopi, 1993. Medio impreso.

- "Colonialidad global, capitalismo y hegemonía epistémica». Culturas imperiales. Experiencia y representación en América, Asia y África. Ricardo Salvatore (comp.). Rosario: Beatriz Viterbo (Editora), 2005. 55-88. Medio impreso.

O'Gorman, Edmundo. «Primera parte: Historia y crítica de la idea del descubrimiento de América». La invención de América. México: FCE, 2003. 13-54. Medio impreso.

Paranaguá, Paulo Antonio (ed.). Cine documental en América Latina. Madrid: Cátedra, 2003. Medio impreso.

Portal del cine y el audiovisual latinoamericano y caribeño. Sitio web, 2010. Fecha de ingreso: 20 de agosto de 2010.

Pratt, Mary Louise. Ojos imperiales. Buenos Aires: Universidad Nacional de Quilmes, 2002. Medio impreso.

Prelorán, Jorge. "Conceptos éticos y estéticos en el cine etnográfico». Imagen y cultura. Perspectivas del cine etnográfico. Ardévol, Elisenda Piera y Luis Pérez-Tolón (coord.). Granada: Diputación Provincial de Granada, 1995. Medio impreso.

Rolle, Claudio. «El documental como monumental: vehículo de memoria». Itinerario del cine documental chileno 1900-1990. Ed. Alicia Vega. Santiago: Universidad Alberto Hurtado, 2006. Medio impreso.

Said, Edward. Orientalismo. Madrid: Libertarias, 1990. Medio impreso. 
Salomón, Frank. «La Textualización de la memoria en la América andina: Una perspectiva etnográfica comparada». Acta Final X Congreso Indigenista Interamericano. Managua: Instituto Indigenista Interamericano, 1993. 229-260. Medio impreso.

Stock, Ann Marie. «El Cine Mudo en América Latina: paisajes, espectáculos e historias». Historia General del Cine Volumen IV América (1915-1928). Talens, Jenaro y Santos Zunzunegui (coord.). Madrid: Cátedra, 1997. Medio impreso.

Tierras Magallánicas, Patagonia. De Agostini, Alberto, dir. b/n. DVD. Congregación salesiana, 1933. Medio fílmico.

Väinö Auer (1895-1981). Piela, Mikko, dir. b/n y color. Silva Mysterium Oy, 2005.Medio fílmico.

Vega, Alicia. Itinerario del cine documental chileno. Santiago: Universidad Alberto Hurtado, 2006. Medio impreso.

\section{FOTOS:}



El sacerdote salesiano Alberto de Agostini junto al cacique Pacheko

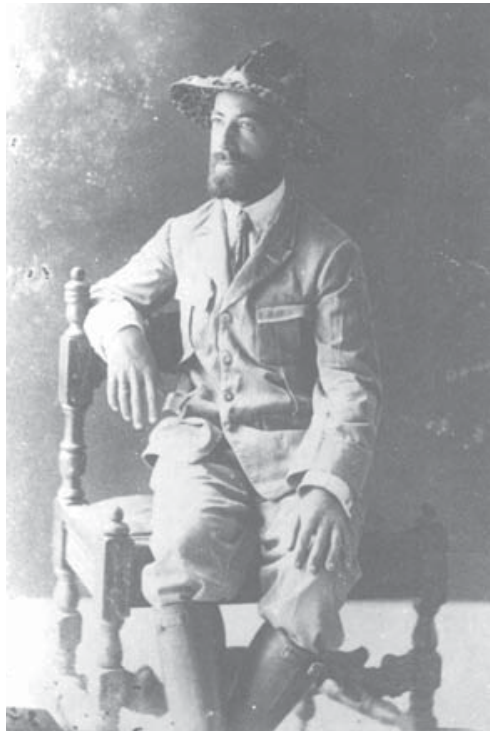

Silvino Santos filmó durante la época silente en la Amazonía. (Fotografía publicada en III Jornada de Cinema Silencioso. Sao Paulo, Cinemateca Brasileña, 2009)

Recepción: 15 de abril de 2010 Aceptación: 31 de mayo de 2010 